\title{
Who is a Middle Manager: A literature Review
}

\author{
Zahra Rezvani* \\ ${ }^{1}$ Technical University of Delft, Jaffalan
}

Received: October 18, 2017; Accepted: October 25, 2017; Published: November 03, 2017

*Corresponding author: Mrs Zahra Rezvani, Technical University of Delft, Jaffalan, 2600 GA Delft, Tel: +31687042596; E-mail: z.rezvani@tudelft.nl

\begin{abstract}
Purpose -The purpose of research is to provide an overview of the researches on the definition of middle management and the roles of middle management in organisations and safety.

Design/methodology/approach - Literature review

Findings - The literature review revealed that the lack of consistency in a holistic typology of middle management and their roles are evident. All authors agree that this intermediate management group is between top level and lower level management which is very broad definition. In addition, middle management group has been distinguished from other managerial groups by three main criteria namely function, the context of the organisation and the researchers tendency. Two prominent tendencies in researches on middle management were first the strategic roles of middle management and the second either the significant contribution of middle management in the management of change or their dysfunctional roles in changes within organisations. There is a considerable overlap between elements of middle management roles, and the extent of the roles depends on the context of the organisation, time, and attitudes of middle managers. A literature review revealed that middle managers implement 5 prominent roles which are strategic, administrative, leadership, decision-making and communication. Researchers were more focus on two categories which are strategic and communication and cooperation roles. While other roles particularly decision-making role of middle management even overlooked in the management domain.
\end{abstract}

Research limitations/implications - Although authors tried to review literature comprehensively, the research may not involve all articles related to middle management.

Originality/value - The paper contributes to the literature by highlighting the middle management identity and their multiple and crucial roles in organisations, as well as management of safety.

Keywords: Middle Management, Review, Decision-Making, Roles.

\section{Introduction}

To achieve organisational objectives in an organisation, different levels of management are involved with different degrees of power, authority, and responsibility. The breath of authority and responsibility in an organisation depends on a clear definition of management level [51]. Since one management level which engages in many unique tasks within the organisation is middle management, it is essential to identify the concept of middle management and to define their functions.
In addition, to successfully implement an effective Occupational Health, Safety Environmental And Quality Management System (OHSQ) in an organisation, resource allocation, employee participation and the commitment of individuals from top management to front-line level is essential [7,36]. This implies a high level of interdependency between different levels in an organisation. However, there are a tendency to study on the senior management, assuming that senior management has the highest responsibility in safety management or focusing on operational level who are directly involved in fieldwork, consequently they are the closest people to accidents, while ignoring middle management who lies between these two extremes $[1,44]$.

Accident causation analysis also revealed that although middle management plays a crucial role in organisations, middle management's roles were not gotten attention in accident investigations. For instance, the BP blowout accident is an evidence which highlights the prominent role of middle managers .When middle managers' decisions were taking them a step on the path to disaster. The Macondo team which includes engineers, well team leader and rig-based well site leaders who are mostly middle managers made the flawed decisions because of contributed causes such as the organisational structure of BP's engineering activity, economic pressure and focusing on personal safety instead of process safety. Moreover, they applied consensus decision making, which is a diffuse accountability instead of a single-point accountability which led them to this accident [27].

Since middle managers overlooked in accident causation analysis, in this paper the scope of the study is extended to safety researchers and other domains to find who a middle manager is exactly, what they are doing in organisations and what the roles of middle managers are in safety specifically. We conducted a review of the literature that would enable us to illustrate the concept of middle management. Furthermore, three other research questions are posed namely:

-What are middle manager's role, their main responsibilities and their authorities in organisations?

-What are middle management roles and their influence in safety management?

-Whether the decisional role is an important role in middle management? If so, how middle managers make decisions based 
on literature review?

In what follows, we will summarise the literature and use them to find above mentioned research questions.

\section{Methods}

Before begins to test causal hypotheses, the investigator has to make sure that the data collected confirm the conceptual structure postulated in advance. For this reason, we reviewed and summarised the relevant published studies about the definition of a middle manager. At first, since our interest was the role of middle management in safety management, a systematic search were conducted on the table of contents of journals in safety field (Safety Science Journal, Accident Analysis \&prevention, and Journal of Safety Research), but there was not any definition regarding to this term and the roles of middle managers; so, we extended the scope of research to three academic databases which were Google scholar, Scopus and Web of Knowledge (Science) to search general scopes of management for identifying the middle management concept as well as the roles of middle management. The bibliographies of references then were searched, as well as Wikipedia and management encyclopaedia.

\section{Result}

In total, we reviewed 60 articles that have some information about the definition of middle management, middle management roles or the middle management influence from 1975 to 2015. The results reveal that investigators have currently a tendency to search for middle management. The researches were mostly performed in the management scope, while in the safety literature, not only little attention has been devoted to the definition of middle manager, but also this essential group is given if not, little room.

Findings show that there was not any paper about definition of middle management in the most safety-related journals such as Safety Science, Accident Analysis \&prevention and Journal of Safety Research; however, there were few articles regarding to the role of middle management in safety journals $[7,18,26,29,37,38,39]$.

There is an inconsistency in the definition of middle managers. There is not an exact definition for a middle manager that is applicable for all organisations and there is not a clear-cut point between this managerial group and other management groups. One criterion which has been applied for identifying middle managers among other managerial levels is their functions in an organisation. Middle management operates in an operational core of the organisation [32]. Another criterion is the position of middle managers in the organisational hierarchy. They are positioned in a level where at least two levels of staff are below them $[14,40,48,49,52]$.The organisation structure or context of the organisation is another essential factor which influenced the definition of middle management $[14,16]$. Even, the purpose of researchers affected the definition of this managerial group. For instance in one hand, Currie and Procter considered locality managers as middle managers who were far from the operational core of the organisation and only one level staff was located below them, because they considered other contextual criteria such as first, they were managing under leadership of a multidisciplinary team; second, the organisational structure was less elaborate; third, they reported into assistant directors which were positioned at corporate headquarters [14]. On the other hand, Brewer considered middle managers in the federal government as frontline supervisors when he studied supervisory tasks. He argued that this managerial group have similar or greater supervisory tasks [8]. Following, we provide a summary of findings of descriptions, important characteristics, and the roles of middle management that deserve special attention.

\section{Discussion}

Literature review reveals that the two prominent trends in researches on middle management are first the strategic contribution of middle management in organisations. The most systematic and widely cited attempt to explore the strategic roles of middle managers were carried out by Floyd and Wo oldridge $[14,19,20,21,22,23,52]$.The second trend has been about either the roles of middle management in organisational change or changing the roles of middle managers as a result of organisational change[2,3,4,5,6,9,10,13,17,30,41,45,46,47].

Managerial roles define as various responsibilities and requirements associated with enacting managerial job. Managerial roles are more than required activities; instead, they encompass the activities, knowledge, skills, and traits are required to enact managerial job. A literature review revealed that managerial roles vary depend on the context of the organisation. In other words, studies show that the requirements of managerial role appear stable within decades; however, the importance of a specific role depends on the context of the organisation and managers can play one or several roles within a given point in time [15].

The lacks of consistency in a holistic typology of middle management roles are evident and there is a considerable overlap between elements of roles [42,52]. However, the purpose of this chapter is to illustrate the role of middle management particularly in safety. Therefore, outlines middle management roles which are categorised to5 prominent roles which are strategic roles, administrative roles, leadership, decision-making and communication (Table 3-1). They can divide into subcategories which are illustrated in Figure 3-1 and Table 3-2[Figure 3-1][Table 3-2].We remind here that the extent of roles depends on the context of the organisation, time and attitudes of middle managers.

Strategic roles of middle managers encompass of championing, synthesising, facilitating and implementing [19]. In the championing role, middle managers present innovative ideas and business opportunities to top management. Categorising and blending both strategic and hands-on information as well as selling issues to top management are activities for carrying the synthesising role [17, 34,52,]. The direction of communication in these roles is upward, while facilitating and implementing roles have downward direction. In the facilitating role, middle managers nourish divergent adaptability to strategy and changes. 
Table 3-1: Description, characters and roles of middle management according to literature review

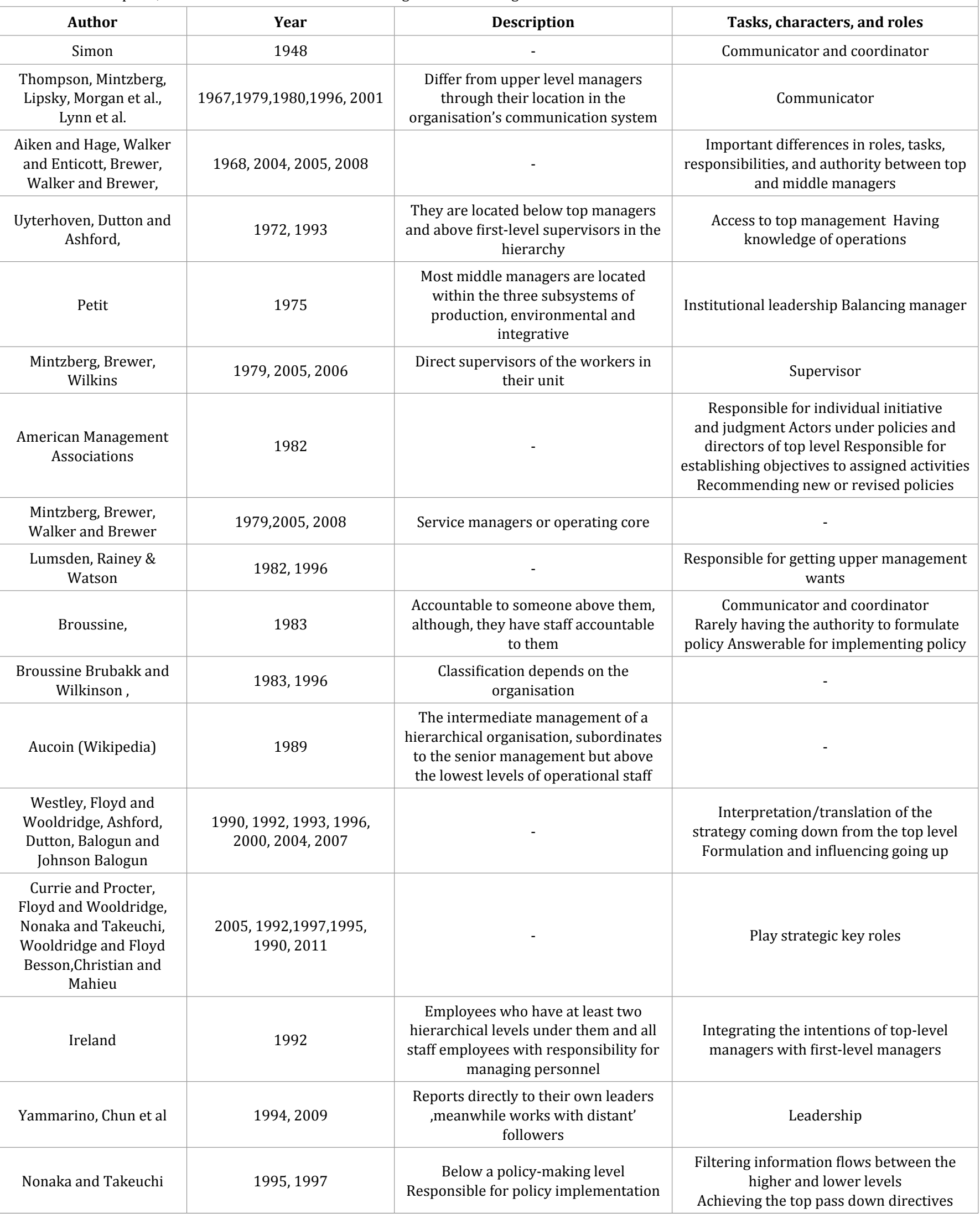




\begin{tabular}{|c|c|c|c|}
\hline Morgan et al. & 1996 & - & $\begin{array}{l}\text { Leadership, networking, allocating } \\
\text { resources, budgeting, scheduling, setting } \\
\text { rules and guidelines for lower level }\end{array}$ \\
\hline $\begin{array}{l}\text { Rainey and Watson, } \\
\text { Caughron and Mumford }\end{array}$ & 1996, 2012 & $\begin{array}{l}\text { Embedded leader who reports to } \\
\text { another high level leader but is also } \\
\text { responsible for leading others }\end{array}$ & Leadership \\
\hline $\begin{array}{l}\text { Rainey and Watson, } \\
\text { Rainey }\end{array}$ & 1996, 2003, & - & Motivator \\
\hline Brubakk and Wilkinson & 1996 & They are in the middle of the hierarchy & $\begin{array}{l}\text { Coping with conflicts between top } \\
\text { management and employees }\end{array}$ \\
\hline Floyd and Wooldridge & 1997 & - & $\begin{array}{l}\text { Coordinator Interpret ambiguous and } \\
\text { diverse data } \\
\text { Frame the perceptions of other managers } \\
\text { Change the strategic agenda }\end{array}$ \\
\hline $\begin{array}{l}\text { Floyd and Wooldridge, } \\
\text { Raes et al. }\end{array}$ & 1997,2011 & - & Accelerator or inhibitor of strategic changes \\
\hline $\begin{array}{l}\text { Floyd \& Wooldridge, Huy, } \\
\text { Raes et al. }\end{array}$ & 199720022011 & $\begin{array}{c}\text { Stuck in the middle, reporting to } \\
\text { executives in higher organisational } \\
\text { levels and managing people in lower } \\
\text { ones }\end{array}$ & - \\
\hline Albert et al & 2000 & Strategy actors & $\begin{array}{l}\text { Transforming, strategizing and constructing } \\
\text { the strategy }\end{array}$ \\
\hline Huy Raman Hope & $2002,2009,2010$ & - & Crucial for success of change \\
\hline Balogun & 2003,2007 & They report to top-level directly & $\begin{array}{l}\text { Linking pins or a conduit Contributor } \\
\text { to strategic decisions Pivotal although } \\
\text { underscored role Connect top management } \\
\text { with the rest of organisation Implement } \\
\text { senior manager orders Direct supervisors } \\
\text { of employees who have long-term contact } \\
\text { with lower level, Concern on the day-to-day } \\
\text { operations of the facility Administrators, } \\
\text { and responsible for more prolonged } \\
\text { responsibilities }\end{array}$ \\
\hline Balogun\& Johnson & 2004 & & $\begin{array}{l}\text { Mediators between organisational units and } \\
\text { functional levels }\end{array}$ \\
\hline Arneson & 2008 & & $\begin{array}{l}\text { Problem solving Communicator Arranger } \\
\text { and implementer of strategy }\end{array}$ \\
\hline $\begin{array}{l}\text { McCann\& Morris } \\
\text { \&Hassard, Yang\& } \\
\text { Zhang\&Tsui }\end{array}$ & $20082010)$ & - & Vast range of responsibility \\
\hline Chun et al. & 2009 & $\begin{array}{l}\text { They are responsible for day-to-day } \\
\text { tasks and peruse the goals of top level } \\
\text { leaders }\end{array}$ & $\begin{array}{l}\text { Expanding higher level leaders Influence } \\
\text { over lower level employees }\end{array}$ \\
\hline Hong-hua\& Yan-hua & 2009 & & Key factor for sustainable development \\
\hline Sun and Anderson & - & $\begin{array}{l}\text { Either complement or contemplate the } \\
\text { top management impact }\end{array}$ & The greater influence on subordinates \\
\hline Johnson & 2011 & $\begin{array}{l}\text { Agree with Brewer, Mintzberg and } \\
\text { Wilkins and described middle managers } \\
\text { based on their tasks. }\end{array}$ & $\begin{array}{l}\text { Gather political support Elevate change } \\
\text { Network Influence others (Leadership) }\end{array}$ \\
\hline Johansen & 2011 & $\begin{array}{l}\text { They are responsible for managing the } \\
\text { operations in a particular, unit, agency } \\
\text { or program. }\end{array}$ & - \\
\hline Johansen & 2011 & $\begin{array}{l}\text { Their tasks are similar in both private } \\
\text { and public sectors }\end{array}$ & $\begin{array}{l}\text { Leadership They allocate resource, network, } \\
\text { communicate, and implement policy }\end{array}$ \\
\hline
\end{tabular}




\begin{tabular}{|c|c|c|c|}
\hline Rouleau and Balogun & 2011 & $\begin{array}{l}\text { They lack the formal role authority } \\
\text { to act strategically Need to influence } \\
\text { upwards as well as downwards }\end{array}$ & Communication bridge Sense making \\
\hline Ghorbal-Ball & 2011 & - & $\begin{array}{l}\text { Developers Identify opportunities to control } \\
\text { costs of projects }\end{array}$ \\
\hline Raelina \&Cataldo & 2011 & - & $\begin{array}{l}\text { Unify divergent systems (executive and } \\
\text { rank-and-file) }\end{array}$ \\
\hline Caughron\& Mumford & 2012 & $\begin{array}{l}\text { Second-tier leader", the leader who } \\
\text { follows, as well as leads }\end{array}$ & $\begin{array}{c}\text { Distant leadership Serve simultaneously as } \\
\text { leaders and followers }\end{array}$ \\
\hline Chang \& Bright & 2012 & - & $\begin{array}{l}\text { Responsible for maintaining stability } \\
\text { Improve the existing services and policies }\end{array}$ \\
\hline Gentry et al. & 2012 & $\begin{array}{l}\text { The direct pipeline for top-level } \\
\text { leadership positions They have at least } \\
2 \text { direct reports and at least one boss } \\
\text { who rate them on performance }\end{array}$ & $\begin{array}{l}\text { Networking Stuck in the middle They } \\
\text { control organisational policies }\end{array}$ \\
\hline $\begin{array}{l}\text { Reeves, Walsh, Tuller } \\
\text { and. Magley }\end{array}$ & 2012 & $\begin{array}{l}\text { direct supervision of employees who } \\
\text { have prolonged contact with inmates } \\
\text { in either custody or program roles and } \\
\text { they focus on the day-to-day operations } \\
\text { of the facility, while directly reporting } \\
\text { to senior-level administrators }\end{array}$ & $\begin{array}{l}\text { Bridging upper management and line } \\
\text { workers Key personnel for organisational } \\
\text { performance Supervisor }\end{array}$ \\
\hline Chang, Bright & 2012 & - & Leader \\
\hline Caughron , Mumford & 2012 & $\begin{array}{l}\text { Occupy an important but overlooked } \\
\text { position }\end{array}$ & - \\
\hline
\end{tabular}

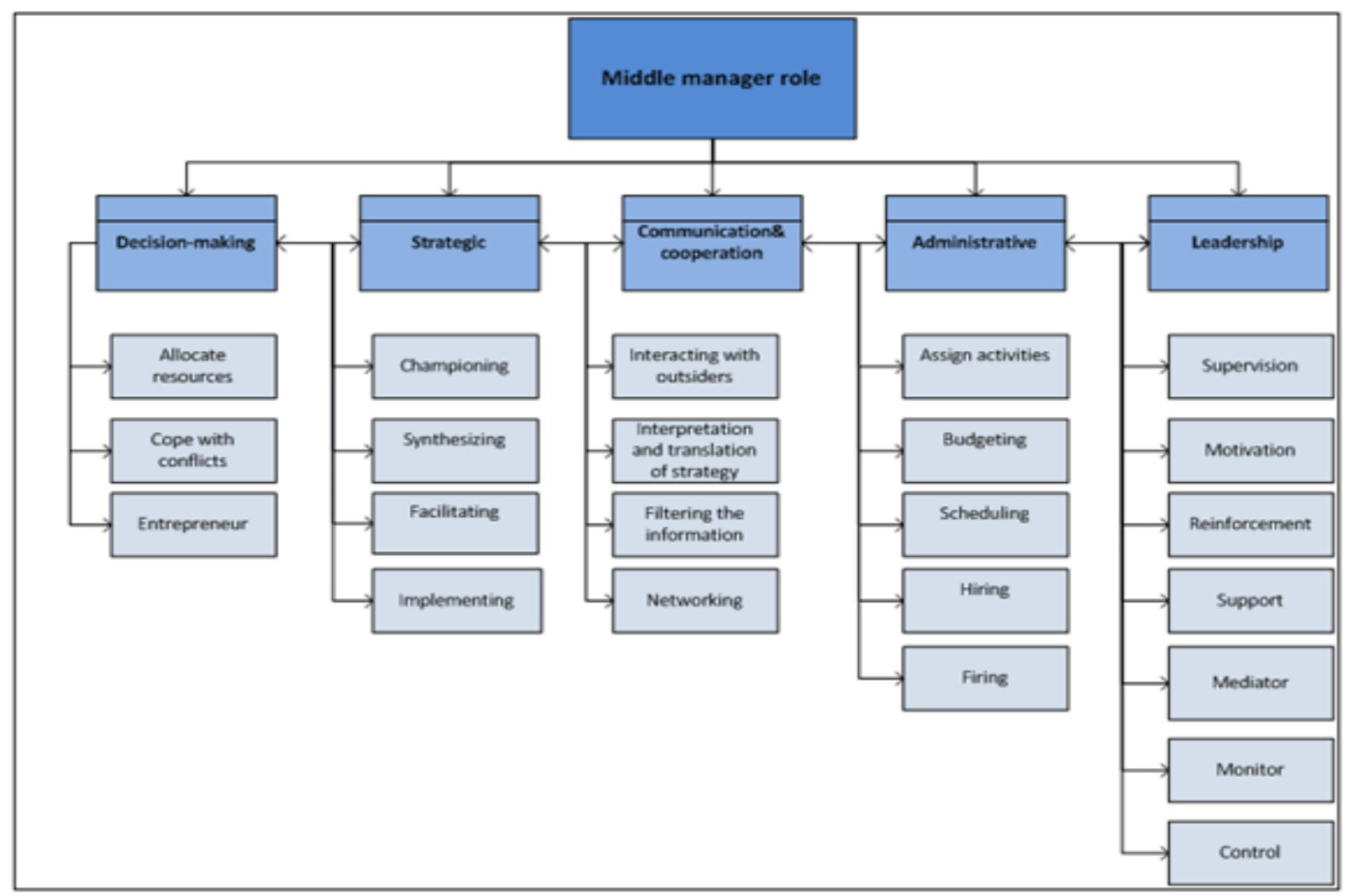

Figure 3.1:Middle management roles according to a literature review. 


\begin{tabular}{|c|c|c|}
\hline Main role & Sub-roles & Direction of information transfer \\
\hline Strategic & $\begin{array}{l}\text { Championing } \\
\text { Synthesising } \\
\text { Facilitating } \\
\text { Implementing }\end{array}$ & $\begin{array}{l}\text { Interpersonal/Upward } \\
\text { Interpersonal/Upward } \\
\text { Interpersonal/Downward } \\
\text { Interpersonal/Downward }\end{array}$ \\
\hline Administrative & $\begin{array}{l}\text { Assign activities } \\
\text { Budgeting } \\
\text { Scheduling } \\
\text { Hiring } \\
\text { Firing }\end{array}$ & $\begin{array}{l}\text { Interpersonal/Downward } \\
\text { Interpersonal/Downward } \\
\text { Interpersonal/Downward } \\
\text { Interpersonal/Downward } \\
\text { Interpersonal/Downward }\end{array}$ \\
\hline Decision-making & $\begin{array}{l}\text { Allocate resources } \\
\text { Cope with conflicts } \\
\text { Entrepreneur }\end{array}$ & $\begin{array}{l}\text { Personal/interpersonal } \\
\text { Interpersonal and personal/ Both horizontal and vertical }\end{array}$ \\
\hline Leadership & $\begin{array}{l}\text { Supervision } \\
\text { Motivation } \\
\text { Reinforcement } \\
\text { Support } \\
\text { Mediator } \\
\text { Monitor } \\
\text { Control }\end{array}$ & $\begin{array}{c}\text { Interpersonal/Downward } \\
\text { Interpersonal/Downward } \\
\text { Interpersonal/Downward } \\
\text { Interpersonal/Downward } \\
\text { Interpersonal/Downward/upward } \\
\text { Interpersonal/Downward } \\
\text { Interpersonal/Downward }\end{array}$ \\
\hline $\begin{array}{l}\text { Communication and } \\
\text { cooperation }\end{array}$ & $\begin{array}{l}\text { Interacting with outsiders } \\
\text { Interpretation and translation of strategy Filtering the } \\
\text { information } \\
\text { Networking }\end{array}$ & $\begin{array}{c}\text { Interpersonal } \\
\text { Personal } \\
\text { Personal } \\
\text { Interpersonal/Both horizon and vertical }\end{array}$ \\
\hline
\end{tabular}

They share information and they can guide adaptation for instance, they can facilitate adequate prioritisation of safety goals and learning [12,31]. Middle managers implement the planned strategy or strategic decisions [10]. They transfer the broad and long-term strategic objectives from corporate centre to individual performance plans and short-term operational objectives which are implemented by local managers in the field [14]. For this purpose, they motivate, coach and inspire their subordinators [19].

Communication and cooperation is another essential role of middle management that consists of interacting with outsiders, interpretation and translation of strategy, filtering the information, and networking. Their particular positions in social network contribute to both inter-organisational collaborative relationship and intra-organisational relationship. In addition, they interact with top management, as well as front-line managers; consequently, they influence both upwards and downwards and horizontal $[46,47]$. Therefore, they have a potential for interaction and multilevel or even better network influences. Middle managers share the common ground as well as disruptions given rise from an external environment to cultivate organisational objectives [28]. Lots of studies on middle management concentrate in this role and strategic role of middle managers, while they left other important roles like administrative and technical roles.

Middle managers are highly experienced segment of the organisation. While, supervisors have good technical skills they are less well in managerial skills. The senior manager on the other hand, performs managerial roles, while they are far from technical skills. Middle managers require both technical and managerial roles. They perform administrative roles such as assign activities, budgeting, scheduling, hiring and firing, at the same time, they should have enough knowledge about technical issues in their units.

Leadership is another essential role for middle management consists of supervision, motivation, reinforcement support, monitor, control, and mediator. Middle managers are leading their departments to achieve organisational goals [13]. Middle managers are embedded leaders or second-tier leader who are leading others, while they report to another high-level leader $[11,43]$.Middle managers demonstrate both transformational and transactional leadership. They utilize transformational leadership by reinforcement, monitor, and control to reinforce their subordinate and to get the support of their subordinates through transactional leadership (e.g. motivation, mediation, making rewards contingent on performance) [42]. Middle managers expand the higher level leaders' influence over lower level employees.They also set rules and guidelines for lower level and they are responsible for maintaining stability, and improving the existing services and policies $[13,33]$.

A literature review revealed the lack of describing and developing decisional roles of middle managers. However, middle managers are semi-autonomous under any circumstances [14]. They have in one hand authority to make decisions; on the other hand, they face with constraints for taking decisions. Middle managers can decide about what to peruse and what not, when is the proper time for performing something or even when to sell the issues to senior managers.

Managers experience the conflict of priorities because of handling different tasks [35]. They perceive conflicts of interest 
[52]. Therefore, a decision to resolve the conflict is one essential part of their main roles. Entrepreneurship relates to how middle managers identify and generate new ideas which can influence the capacity of innovation in organisations. They can be the primary source of entrepreneur initiatives or they can improve entrepreneurship of frontline managers by supporting and coaching of new ideas of frontline supervisors [52].

\section{Conclusion}

Our objective in this chapter is to provide an overview of research on the definition of middle management and the roles of middle management in organisations and safety. Literature review in safety scope revealed that middle management entirely overlooked in safety. Assessment of other articles did not indicate the clear definition of middle management which clarifies the boundary between this group and other management groups and is applicable for every organisation. Literature review shows that all authors agree that this intermediate management group are between top level/central management and lower level/ outer edges management which is very broad definition. In addition, identifying the middle management group from other managerial groups depends on three main criteria namely function, the context of the organisation and the researcher tendency.

The review provides evidence that middle management impact organisations in a various way by performing different roles. Two prominent tendencies in researches on middle management research were first the strategic roles of middle management and the second either the significant contribution of middle management in the management of change or their dysfunctional roles in changes within organisations. As mentioned in cahpter2, did not manage the change was one of the hidden reasons of Tesoro accident and Macondo blowout.

The academic literature on safety has long neglected the role of middle managers. While there are a fair number of studies about the role of top management in safety. There are many reasons to believe that middle managers are key actors who play important roles in organisations and safety. The main reason is their multiple roles in organisations. In addition, adverse events are likely to occur as a result of systemic and organisational factors such as inadequate strategic decision making, weak management, insufficient training, poor communications, and improper procedures which closely links with middle managers who are located in pivotal positions and they perform crucial multiple roles.

Middle management performs multiple roles in organisations. According to the literature review, we concluded that middle managers take 5 essential roles which are strategic, administrative, leadership, communication and cooperation, and decision-making. Researchers were more focus on two categories which are strategic and communication and cooperation roles. While other roles particularly decision-making role of middle management even overlooked in the management domain.

Decision-making can be consist of recourse allocation, entrepreneurship and disturbance handling. Middle management continually faces with conflicts which give rise form deviation in normal conditions. It can be the conflict as a result of technical disturbance or disturbance between other elements of an organisation like individuals in different levels or even conflict can occur between an organisation and other organisations which have relation with the main organisation. Because middle managers are located in the middle part of organisation between operating core, strategic apex, support staff and techno structure they can face with more disturbance and they have to resolve the conflict for proper management. Middle managers have limited authority to allocate resources. The span of authority might be influenced by the context of the organisation. Yet, they have authority to prioritize one objective that can be production to other objectives for instance safety; consequently, they are responsible for decisions within their authority.

Given the limited number of studies on middle management in safety domain, future studies are needed to examine the role and influence of middle management in safety management specifically in safety-related decision-making.

\section{Acknowledgement}

The authors would like to appreciate the Health Ministry of Iran and Technical University of Delft for their financial and administrativel support to undertake this study.

\section{References}

1. Anderson JC, Cleveland G, Schroeder RG. Operations strategy: A literature review. Journal of Operations Management. 1989; 8(2):133-158. doi:10.1016/0272-6963(89)90016-8

2. Balogun J. From blaming the middle to harnessing its potential: Creating change intermediaries. British Journal of Management. 2003;14(1):69-83. doi:10.1111/1467-8551.00266

3. Balogun J. The Practice of Organizational Restructuring: European Management Journal. 2007;25(2):81-91. doi:10.1016/j. emj.2007.02.001

4. Balogun J. The Practice of Organizational Restructuring: From Design to Reality. European Management Journal. 2007;25(2):81-91. doi:10.1016/j.emj.2007.02.001

5. Beck TE, Plowman DA. Experiencing Rare and Unusual Events Richly: The Role of Middle Managers in Animating and Guiding Organizational Interpretation. Organization Science. 2009;20(5):909-924. doi:10.1287/orsc.1090.0451

6. Besson P, Mahieu C. Strategizing from the middle in radical change situations: Transforming roles to enable strategic creativity. International Journal of Organizational Analysis. 2011;19(3):176-201

7. Bhattacharya S, Tang L. Middle managers' role in safeguarding OHS: The case of the shipping industry. Safety Science. 2012; 51(1):63-68. doi.org/10.1016/j.ssci.2012.05.015

8. Brewer GA. In the Eye of the Storm: Frontline Supervisors and Federal Agency Performance. Journal of Public Administration Research and Theory. 2005;15(4):505-527. doi:10.1093/jopart/mui031

9. Brubakk B, Wilkinson A. Changing roles of middle management? A case study of bank branch management. Journal of Retailing and Consumer Services. 1996;3(3):163-174.

10. Buss WC, Kuyvenhoven R, Consulting T. Perceptions of European Middle Managers of their role in Strategic Change. Global Journal of Business Research. 2011;5(5):109-119 
11. Caughron JJ, Mumford MD. Embedded leadership: How do a leader's superiors impact middle-management performance? The Leadership Quarterly. 2012;23(3):342-353. doi:10.1016/j.leaqua.2011.08.008

12. Chakravarthy BS. Adaptation: A Promising Metaphor for Strategic Management. The Academy of Management Review. 1982;7(1):35-44.

13. Chang A, Bright K. Changing roles of middle managers in academic libraries. Library Management. 2012;33(4,5):213-220. doi:10.1108/01435121211242263

14. Currie G, Procter SJ. The Antecedents of Middle Managers' Strategic Contribution: The Case of a Professional Bureaucracy. Journal of Management Studies. 2005;42(7):1325-1356. doi:10.1111/j.14676486.2005.00546.x

15. Dierdorff EC, Rubin RS, Morgeson FP. The milieu of managerial work: an integrative framework linking work context to role requirements. The Journal of Applied Psychology. 2009;94(4):972-988. doi:10.1037/ a0015456

16. Dopson S, Stewart R. What is Happening to Middle Management? British Journal of Management. 1990;1(1):3-16. doi:10.1111/j.1467-8551.1990.tb00151.x

17. Dutton JE, Ashford SJ, Neill RMO, Lawrence KA. Moves that matter: issue selling and organizational. Academy of Management Journal. 2001;44(4):716-736.

18. Flin R, Yule S. Leadership for safety: industrial experience. Quality and Safety in Health Care. 2004;13(suppl2):ii45-ii51. doi:10.1136/ qshc.2003.009555

19. Floyd SW, Lane P J. Strategizing throughout the Organisation: Managing Role conflic in Strategic Renewal. Academy of Management Review. 2000;25(1):154-177.

20. Floyd SW, Wooldridge B. The strategic middle manager: How to create and sustain competitive advantage. San Francisco: Jossey-Bass Publishers. 1996.

21. Floyd SW, Wooldridge B. "Middle management's strategic influence and organizational performance." APA. Journal of Management Studies. 1997;34(3):465-485. doi:10.1111/1467-6486.00059

22. Floyd SW, Wooldridge B. Knowledge creation and social networks in corporate entrepreneurship: The renewal of organizational capability. Entrepreneurship: Theory and Practice. 1999;23(3):123-123.

23. Floyd SW, Wooldridge B, Wiley J. Middle management involvement in Strategy and its association with type: A research strategic note. Strategic Management Journal. 1992;13:153-167.

24. Gentry WA, Cullen KL, Sosik JJ, Chun JU, Leupold CR, Tonidandel S. Integrity's place among the character strengths of middle-level managers and top-level executives. The Leadership Quarterly. 2013;24(3):395-404. doi:10.1016/j.leaqua.2012.11.009

25. Ghorbal-Blal I. The role of middle management in the execution of expansion strategies: The case of developers' selection of hotel projects. International Journal of Hospitality Management. 2011;30(2):272-282. doi:10.1016/j.ijhm.2010.09.007

26. Hayes J. Use of safety barriers in operational safety decision making Safety Science. 2012;50(3):424-432. doi:10.1016/j.ssci.2011.10.002

27. Hopkins A. Disastrous decisions: the human and organisational causes of the Gulf of Mexico blowout. CCH Australia Ltd. 2012.

28. Kodama M. Knowledge creation through networked strategic communities. Long Range Planning. 2005;38(1):27-49. doi:10.1016/j. Irp.2004.11.011

29. Littauer SB, Yegulalp TM, Zahariev GK. A framework for optimizing managerial decision. Omega. 1976;4(1):35-48. doi:10.1016/03050483(76)90037-2
30. Manville G, Greatbanks R, Krishnasamy R, Parker DW. Critical success factors for Lean Six Sigma programmes: a view from middle management. International Journal of Quality \& Reliability Management. 2012;29(1):7-20. doi:10.1108/02656711211190846

31. Mintzberg H. Patterns in strategy formation. Management Science. 1978;24(9):934-948. doi:10.1287/mnsc.24.9.934

32. Mintzberg H. Structure in 5 â€TM s : A Synthesis of the Research on Organization Design. 1980;26(3):322-341.

33. Morgan D, Bacon KG, Bunch R, Cameron CD, Deis R. What Middle Managers Do in Local Government: Stewardship of the Public Trust and the Limits of Reinventing Government. Public Administration Review. 1996;56(4):359-366.

34. Nonaka I. Toward middle-up-down management: Accelerating information creation. Sloan Management Review. 1988;29(3).

35. Nordlof $\mathrm{H}, \mathrm{Wijk} \mathrm{K}$, Lindberg PA. Comparison of Managers ' and Safety Delegates ' Perceptions of Work Environment Priorities in the Manufacturing Industry. Human Factors and Ergonomics in Manufacturing \& Service Industries. 2012;22(3):235-247. http://doi. org $/ 10.1002 / \mathrm{hfm}$

36. Nytro K, Saksvik PO, Torvatn H. Organizational prerequisites for the implementation of systematic health, environment and safety work in Enterprises. Safety Science. 1998;30(3):297-307. doi:10.1016/ S0925-7535(98)00050-2

37. O'Dea A, Flin R. The role of managerial leadership in determining workplace safety outcomes. Suffolk: Petersen. 1998.

38. O'Dea A, Flin R. Site managers and safety leadership in the offshore oil and gas industry. 2001;37(1):39-57. doi:10.1016/ S09257535(00)00049-7

39. Petersen D. Safety management 2000 : Our strengths \& weaknesses. Professional Safety. 2000;45(1):16-19.

40. Pugh DS, Hickson DJ, Hinings CR, Turner C. Dimensions of organizational structure. Administrative Science Quarterly. 1968;13(1):65-105. doi:10.2307/2391262

41. Raelin JD, Cataldo CG. Whither Middle Management? Empowering Interface and the Failure of Organizational Change. Journal of Change Management. 2011;11(4):481-507. doi:10.1080/14697017.2011.63 0509

42. Rainey HG, Watson SA. Transformational leadership and middle management: towards a role for mere mortals. International Journal of Public Administration. 2007;19(6):763-800. doi:10.1080/01900699608525120

43. Reeves DW, Walsh BM, Tuller MD, Magley VJ. The Positive Effects of Participative Decision Making for Midlevel Correctional Management. Criminal Justice and Behavior. 2012;39(10):1361-1372. doi:10.1177/0093854812453127

44. Roger I, Flin R, Mearns KJ, Hetherington C. Safety Leadership: A View of the Senior Managers\&apos; Role. In Offshore Europe. Society of Petroleum Engineers. 2009. doi:10.2118/124322-MS

45. Rouleau L. Micro-Practices of Strategic Sensemaking and Sense giving : How Middle Managers Interpret and Sell Change Every Day. Jurnal of Management Studies. 2005;42(7):1413-1441. doi:10.1111/ j.1467-6486.2005.00549.x

46. Rouleau L, Balogun J. Middle Managers, Strategic Sensemaking, and Discursive Competence. Journal of Management Studies. 2011;48(5):953-983. doi:10.1111/j.1467-6486.2010.00941.x

47. Rouleau L, Balogun J. Middle Managers, Strategic Sensemaking, and Discursive Competence. Journal of Management Studies. 2011;48(5):953-983. doi:10.1111/j.1467-6486.2010.00941.x 
48. Smith V. Managing in the Corporate Interest: Control and Resistance in an American Bank. University of California press. Berkeley, CA: University of California Press. 1997.

49. Staehle W, Schirmer F. Lower-Level and Middle-Level Managers as the Recipients and Actors of Human-Resource Management. International Studies of Management \& Organization. 1992;22(1):67-89.

50. Sun PYT, Anderson MH. The combined influence of top and middle management leadership styles on absorptive capacity. Management Learning. 2011;43(1):25-51. doi: 10.1177/1350507611405116
51. Tenah KA. Management level as defined and applied within a construction organization by some US contractors and engineers. Project Management. 1986;4(4):195-204. doi:10.1016/02637863(86)90003-7

52. Wooldridge B, Schmid T, Floyd SW. The Middle Management Perspective on Strategy Process: Contributions, Synthesis, and Future Research. Journal of Management. 2008;34(6):1190-1221. doi:10.1177/0149206308324326 